\title{
PENINGKATAN KEAKTIFAN DAN HASIL BELAJAR IPA PADA PEMBELAJARAN TEMATIK MENGGUNAKAN PBL
}

\author{
Erviyanti Pramudya \\ PGSD FKIP Universitas Kristen Satya Wacana \\ Jl. Diponegoro 52-60 Salatiga \\ Email: erviyantipramudya@gmail.com
}

Firosalia Kristin

PGSD FKIP Universitas Kristen Satya Wacana

J1. Diponegoro 52-60 Salatiga

Email: firosalia.kristin@uksw.edu

Indri Anugraheni

PGSD FKIP Universitas Kristen Satya Wacana

J1. Diponegoro 52-60 Salatiga

Email: indri.anugraheni@uksw.edu

\begin{abstract}
The purpose of this research is to explain the steps of Problem Based Learning model to increase student involvement in learning and the result of the learning, knowing the enhancement of the student involved, and knowing the growth of student's learning result. The form of this research is Classroom Action Research which it should be done in two cycles. This research has been done in First Noborejo National Elementary School and the subject of this research is fourth-grade students consists of 34 people. The data collection technic of this research is using test and non-test technic. The technic that we used to analyze all the data is quantitative and qualitative descriptive analysis. The result of this research showing that applying steps of Problem Based Learning Model which is orientated student on the problem, organizing student to learn, guide the individual and social experience, developing and providing masterpiece of the student, also analyzing and evaluating problem-solving process, an increased student involved and science learning outcomes in thematic learning on fourth grade student of First Noborejo National Elementary School. The proof of this research's result is the growth of students involved from their first condition (pre-cycle) which was 77,47 and categorized as less active and after using this model, for the first cycle, it increased and reached 95,44 with category pretty active. In the second cycle, the average of the student involved increased become 118,32 with category active. The student learning outcomes also increased with the first learning outcomes average (pre-cycle) is 62,17 and only 13 students that pass the test $(38,23 \%)$. It becomes better with the average grades of student's learning outcomes is 78,39 and 23 students passed the test $(67,64 \%)$. On the second cycle, the average grades of the student learning outcomes are 83,29 and 28 students passed the test $(82,36)$.
\end{abstract}

Keywords:

Involved, Learning outcomes, problem based learning

\begin{abstract}
Abstrak
Tujuan dari penelitian ini adalah untuk mendeskripsikan langkah-langkah penerapan model pembelajaran Problem Based Learning dalam meningkatkan keaktifan dan hasil belajar, mengetahui peningkatan keaktifan siswa, dan mengetahui peningkatan hasil belajar siswa. Jenis dari penelitian ini adalah Penelitian Tindakan Kelas (PTK) yang dilakukan dalam 2 siklus. Penelitian ini dilaksanakan di SD Negeri Noborejo 01 dengan subjek penelitian siswa kelas 4 SD Negeri Noborejo 01 dengan jumlah subjek 34 siswa. Teknik pengumpulan data menggunakan teknik tes dan teknik non tes. Analisis data yang digunakan adalah analisis deskriptif kuantitatif dan kualitatif. Hasil penelitian menunjukkan bahwa dengan penerapan langkah-langkah model pembelajaran Problem Based Learning yaitu orientasi siswa pada masalah, mengorganisasikan siswa untuk belajar, membimbing pengalaman individu atau kelompok, mengembangkan dan menyajikan hasil karya, serta menganalisis dan mengevaluasi proses pemecahan masalah dapat meningkatkan keaktifan dan hasil belajar IPA pada pembelajaran tematik siswa kelas 4 SD Negeri Noborejo 01. Hal tersebut dibuktikan dari meningkatnya rata-rata keaktifan siswa dari kondisi awal (pra siklus) yaitu 77,47 dengan kategori kurang aktif menjadi 95,44 dengan kategori cukup aktif pada siklus I dan pada siklus II rata-rata keaktifan siswa 118,32 dengan kategori aktif. Peningkatan juga terjadi pada hasil belajar siswa dengan rata hasil belajar pada kondisi awal (pra siklus) 62,17 dengan jumlah siswa yang tuntas sebanyak 13 siswa $(38,23 \%)$ mengalami peningkatan pada siklus I dengan rata-rata nilai 78,39 dengan jumlah siswa tuntas sebanyak 23 siswa $(67,64 \%)$ dan pada siklus II rata-rata nilai siswa adalah 83,29 dengan jumlah siswa tuntas sebanyak 28 siswa $(82,36 \%)$.
\end{abstract}

Kata Kunci :

Keaktifan; Hasil Belajar; Problem Based Learning 


\section{A. PENDAHULUAN}

Dunia pendidikan di Indonesia saat ini telah menerapkan kurikulum baru yaitu kurikulum 2013 atau K13. Berbeda dengan kurikulum yang diterapkan sebelumnya, dalam kurikulum 2013 ini pembelajaran lebih berpusat pada siswa (Student centered). Kurikulum 2013 berpusat pada siswa dengan pembelajaran yang bersifat kontekstual, khususnya terkait dengan pembelajaran tematik. Pedoman implementasi Kurikulum 2013 memfokuskan pada lima tahapan pembelajaran mulai dari mengamati (observing). menanyakan (questioning), melakukan percobaan (experimenting), mengumpulkan dan menghubungkan informasi (collecting and associating), dan mengkomunikasikan (communicating). Pembelajaran dalam Kurikulum 2013 menuntut perubahan pola dari teaching centered learning (TCL) ke arah student centered learning (SCL) (Mulyasa, 2015:48). Dalam kurikulum 2013 pembelajaran dilaksanakan dengan model pembelajaran integratif atau dengan kata lain menggabungkan beberapa muatan pembelajaran yang dikemas dalam bentuk pembelajaran tematik terpadu. Pembelajaran tematik dapat diartikan sebagai pembelajaran yang memuat konsep pembelajaran terpadu yang menggunakan tema untuk mengaitkan beberapa mata pelajaran sehingga dapat memberikan pengalaman bermakna kepada siswa Hajar (2013:21). Sedangkan menurut (Rusman, 2012: 254), pembelajaran tematik merupakan salah satu pembelajaran terpadu yang merupakan suatu sistem pembelajaran yang dapat memungkinkan siswa baik secara individu maupun kelompok lebih aktif untuk menggali dan menemukan konsep serta prinsip-prinsip keilmuan holistic, bermakna, dan autentik Kesimpulannya adalah pembelajaran tematik merupakan gabungan dari beberapa muatan pelajaran yang dalam implementasinya pembelajaran tersebut lebih menekankan pada keterlibatan secara aktif oleh siswa dalam proses belajar secara aktif dalam proses pembelajaran, sehingga siswa memperoleh pengalaman secara langsung dan terlatih untuk menemukan sendiri berbagai pengetahuan yang dipelajarinya. Dalam pembelajaran tematik terdapat beberapa integrasi dari berbagai muatan pelajaran termasuk didalamnya adalah IPA. Acista (2014:96) mengemukakan bahwa IPA merupakan proses kreatif dan mencari berbagai sebab akibat dari fenomena-fenomena yang terjadi di alam. Keberhasilan dalam proses belajar mengajar diperlukan adanya strategi dan pola pembelajaran yang aktif dan dinamis serta menyenangkan sehingga dapat membangkitkan kreativitas belajar siswa. Dengan kata lain dalam belajar IPA siswa diminta untuk aktif mempelajari peristiwa-peristiwa dan menghubungkannya dengan kehidupan nyata mereka sendiri, maka disinilah siswa diminta untuk menunjukkan keaktifannya.

Observasi yang dilakukan peneliti pada kelas 4 SD Negeri Noborejo 01 menunjukkan bahwa tingkat keaktifan masih sangat rendah. Hal ini didukung dengan data dari 34 siswa yang terdapat pada kelas 4 hanya 1 siswa $(2,94 \%)$ yang terlihat aktif sekali, 2 siswa $(5,88 \%)$ aktif, 1 siswa $(2,94 \%)$ cukup aktif, dan 22 siswa $(64,71 \%)$ tidak aktif dan 8 siswa $(23,53 \%)$ kurang aktif sekali. Rata-rata keaktifan siswa hanya sebesar 77,47 dengan kategori kurang aktif. Tidak hanya keaktifan siswa saja yang masih kurang, tetapi dalam hasil belajar siswa sebagian besar siswa masih kurang. Hal ini terbukti ketika peneliti melakukan observasi dengan melihat nilai PTS siswa kelas 4 pada muatan pelajaran IPA, ternyata masih banyak siswa SDN Noborejo 01 yang nilainya kurang memuaskan atau dibawah KKM yang ditetapkan oleh sekolah yaitu 70. Sebanyak 13 siswa $(38,23 \%)$ dari 34 siswa yang sudah mencapai KKM, sedangkan 21 siswa $(61,77 \%)$ belum mencapai KKM. Oleh sebab itu, untuk mengoptimalkan pencapaian tujuan pembelajaran diperlukan sebuah model pembelajaran yang dapat memancing keaktifan dari siswa yang nantinya siswa akan mendapatkan pembelajaran yang bermakna.

Berdasarkan hasil observasi diatas maka dapat dilihat bahwa keaktifan dan hasil belajar IPA siswa kelas 4 masih rendah. Pamungkas (2018: 288) keaktifan belajar siswa merupakan suatu proses pembelajaran yang membuat siswa aktif dalam kegiatan pembelajaran. Sunarto (2013) menyatakan bahwa keaktifan adalah kegiatan atau aktivitas atau 
segala sesuatu yang dilakukan atau kegiatankegiatan yang terjadi baik fisik maupun non fisik. Berdasarkan pengertian tersebut dapat disimpulkan bahwa keaktifan merupakan sebuah kegiatan pengajaran yang melibatkan siswa dalam proses pembelajaran. Salah satu penilaian proses pembelajaran adalah melihat sejauh mana keaktifan siswa dalam mengikuti proses belajar mengajar. Menurut Sudjana (2004: 61) menyatakan keaktifan siswa dapat dilihat dalam hal: (1) turut serta dalam melaksanakan tugas belajarnya; (2) terlibat dalam pemecahan masalah; (3) Bertanya kepada siswa lain atau guru apabila tidak memahami persoalan yang dihadapinya; (4) Berusaha mencari berbagai informasi yang diperlukan untuk pemecahan masalah; (5) Melaksanakan diskusi kelompok sesuai dengan petunjuk guru;(6) Menilai kemampuan dirinya dan hasil-hasil yang diperolehnya; (7) Melatih diri dalam memecahkan soal atau masalah yang sejenis; (8) Kesempatan menggunakan atau menerapkan apa yang diperoleh dalam menyelesaikan tugas atau persoalan yang dihadapinya.Ketika siswa terlibat secara aktif dalam kegiatan pembelajaran maka secara tidak langsung hal tersebut juga berpengaruh terhadap hasil belajar siswa.

Slameto (2010: 2) mengemukakan bahwa hasil belajar merupakan suatu proses perubahan tingkah laku sebagai hasil dari interaksi dengan lingkungan dalam memenuhi kebutuhan hidupnya, perubahanperubahan tersebut akan nyata dalam seluruh aspek tingkah laku. Menurut Rusman (2016: 129) hasil belajar adalah sejumlah pengalaman yang diperoleh siswa yang mencakup ranah kognitif, afektif, dan psikomotorik.Hasil belajar merupakan hasil dari suatu interaksi tindak belajar dan tindak mengajar. Dari sisi guru, tidak mengajar diakhiri dengan kegiatan penilaian hasil belajar. Dari sisi siswa, hasil merupakan berakhirnya penggal dan puncak proses belajar. Hasil belajar dapat dibedakan menjadi dampak pembelajaran (prestasi) dan dampak pengiring (hasil). Dampak pembelajaran adalah hasil yang dapat diukur dalam setiap pelajaran (pada umumnya menyangkut domain kognitif). Dampak pengiring adalah terapan pengetahuan dan kemampuan di bidang lain yang merupakan suatu transfer belajar (Arifin, 2013:298). Kristin (2016:78) menyatakan hasil belajar adalah hasil yang diperoleh akibat dari suatu aktivitas yang dilakukan dan mengakibatkan terjadinya perubahan tingkah laku. Menurut Anugraheni (2017: 249) hasil belajar merupakan sebagian besar dari kegiatan atau perilaku yang diperlihatkan oleh seseorang. Berdasarkan beberapa pendapat ahli mengenai definisi hasil belajar, dapat dikatakan bahwa hasil belajar adalah segala upaya yang dilakukan untuk mengubah tingkah laku siswa yang mencakup ranah kognitif, afektif, dan psikomotorik yang dapat diukur dengan menggunakan teknik tes dan non tes.

Berdasarkan masalah yang ditemukan diatas maka diperlukan solusi untuk pemecahan masalah dengan menggunakan model atau metode pembelajaran yang sesuai dengan karakteristik siswa. Salah satu metode yang sesuai adalah dengan menggunakan model pembelajaran Problem Based Learning untuk meningkatkan keaktifan dan hasil belajar siswa. Dengan menggunakan model pembelajaran ini diharapkan mampu membuat aktivitas pembelajaran menjadi lebih bermakna dan keaktifan siswa juga akan nampak pada saat proses pembelajaran, sehingga hasil belajar siswa dapat mencapai nilai KKM. Problem Based Learning merupakan suatu pendekatan pengajaran yang menggunakan masalah dunia nyata sebagai konteks bagi siswa untuk belajar secara aktif untuk pemecahan masalah, serta untuk memperoleh pengetahuan dan konsep yang esensial dari materi pelajaran (Nurhadi, dkk, 2009:16). Pembelajaran yang menggunakan model Problem Based Learning menekankan pada keaktifan siswa untuk menyelesaikan suatu masalah. Menurut Barrow (Huda, 2013:271) mendefinisikan Problem Based Learning sebagai pembelajaran yang diperoleh melalui proses menuju pemahaman akan resolusi suatu masalah. Model pembelajaran ini menyajikan suatu masalah yang nyata bagi siswa sebagai awal pembelajaran kemudian diselesaikan melalui penyelidikan dan diterapkan dengan menggunakan pendekatan pemecahan masalah.Problem Based Learning adalah model pembelajaran yang mengakomodasi keterlibatan siswa dalam belajar dan pemecahan masalah otentik. Menurut Gunantara (2014) Problem Based Learning merupakan model pembelajaran yang melibatkan siswa dalam memecahkan masalah nyata. Model ini menyebabkan motivasi dan rasa ingin tahu menjadi 
meningkat. Model PBL juga menjadi wadah bagi siswa untuk dapat mengembangkan cara berpikir kritis dan keterampilan berpikir yang lebih tinggi.

Berdasarkan beberapa uraian mengenai pengertian Problem Based Learning, dapat disimpulkan bahwa Problem Based Learning adalah pendekatan pembelajaran menyajikan masalah kontekstual, dan pengembangan pemahaman tentang topik-topik, siswa belajar bagaimana mengkonstruksi kerangka masalah, mengorganisasikan dan menginvestigasi masalah, mengumpulkan dan menganalisis data, menyusun fakta, mengkonstruksi argumen mengenai pemecahan masalah, bekerja secara individual atau berkolaborasi dalam pemecahan masalah. Model pembelajaran Problem Based Learning adalah suatu proses pembelajaran yang pada saat proses pembelajaran materi dihubungkan dengan pengalaman nyata dari siswa dan juga dihubungkan dengan kondisi di lingkungan sekitar agar nantinya siswa mampu belajar aktif dan berpikir secara konkret.

Tujuan penelitian ini adalah: (1) untuk mendeskripsikan langkah-langkah penerapan model pembelajaran Problem Based Learning dalam meningkatkan keaktifan dan hasil belajar IPA pada pembelajaran tematik dengan menggunakan model pembelajaran Problem Based Learning siswa kelas 4 SD Negeri Noborejo 01 Salatiga. (2) untuk meningkatkan keaktifan pada pembelajaran tematik dengan menggunakan model pembelajaran Problem Based Learning siswa kelas 4 SD Negeri Noborejo 01 Salatiga. (3) untuk meningkatkan hasil belajar pada pembelajaran tematik dengan menggunakan model pembelajaran Problem Based Learning siswa kelas 4 SD Negeri Noborejo 01 Salatiga.

Berdasarkan latar belakang masalah dan kajian pustaka maka hipotesis dalam penelitian ini adalah : (1) melalui penerapan langkah-langkah yang terdapat dalam model pembelajaran Problem Based Learning yang meliputi orientasi siswa pada masalah, mengorganisasikan siswa untuk belajar, membimbing pengalaman individu/kelompok, mengembangkan dan menyajikan hasil karya, menganalisis dan mengevaluasi proses pemecahan masalah dapat meningkatkan keaktifan dan hasil belajar IPA pada pembelajaran tematik dengan menggunakan model pembelajaran problem Based
Learning siswa kelas 4 SD Negeri Noborejo 01 Salatiga. (2) melalui penerapan model pembelajaran Problem Based Learning dapat meningkatkan keaktifan siswa pada pembelajaran tematik siswa kelas 4 SD Negeri Noborejo 01 Salatiga. (3) melalui penerapan model pembelajaran Problem Based Learning dapat meningkatkan hasil belajar IPA siswa pada pembelajaran tematik siswa kelas 4 SD Negeri Noborejo 01 Salatiga.

\section{METODOLOGI PENELITIAN}

Penelitian ini adalah Penelitian Tindakan Kelas (PTK) dengan menggunakan empat tahapan yaitu perencanaan, pelaksanaan tindakan, observasi, dan refleksi.. Penelitian tindakan kelas adalah sebuah strategi yang dapat digunakan guru untuk mengetahui berbagai masalah yang berhubungan dengan pembelajaran di kelas. Peneliti sebagai perencana kegiatan pembelajaran dan guru sebagai pelaksana kegiatan pembelajaran. Peneliti dibantu oleh teman sejawat guna mengobservasi kegiatan pembelajaran yang berkaitan dengan keaktifan. Subjek dalam penelitian ini adalah siswa kelas 4 SD Negeri Noborejo 01 Salatiga yang berjumlah 34 siswa dengan rincian 17 siswa laki-laki dan 17 siswa perempuan. Penelitian ini dilaksanakan dengan dua siklus. Mawardi (2014:119) mengemukakan bahwa siklus pembelajaran minimal 2 siklus. Siklus I pada tanggal 13 Februari 2019 sampai selesai dan siklus II dilaksanakan pada tanggal 18-20 Februari 2019. Penelitian ini dibagi menjadi dua siklus dengan alokasi waktu $3 \times 35$ menit setiap pertemuannya.

Teknik pengumpulan data yang digunakan dalam penelitian ini adalah teknik tes dan non tes. Teknik pengumpulan data berupa tes tertulis dengan bentuk pilihan ganda digunakan untuk mengukur hasil belajar IPA siswa pada pembelajaran tematik tema 6 subtema 3. Sedangkan lembar observasi diisi oleh observer yang telah ditunjuk peneliti yang digunakan untuk mengukur keaktifan siswa pada saat proses pembelajaran.

Teknik analisis data yang digunakan adalah data deskriptif kuantitatif dan kualitatif. Data yang diperoleh dari hasil tes yang berbentuk pilihan ganda, lembar observasi dan rubrik yaitu data kuantitatif dalam bentuk numerik (data berupa angka) dan data kualitatif yang berbentuk 
penjelasan. Kemudian data kuantitatif tersebut dianalisis menggunakan deskriptif komparatif dengan membandingkan kondisi pada pra siklus, siklus I dan II. Dari hasil tersebut maka dapat diketahui bahwa peningkatan kualitas pembelajaran yaitu proses pembelajaran dan hasil pembelajaran pada kegiatan belajar menggunakan pembelajaran tematik dengan menggunakan model pembelajaran Problem Based Learning.

Indikator keberhasilan dalam penelitian ini dibagi menjadi dua : (1) indikator proses, dimana keberhasilan proses dapat dilihat dari perubahan dalam proses pembelajaran tematik pada muatan pelajaran IPA dengan menggunakan model pembelajaran Problem Based Learning, yaitu melakukan semua langkah-langkah pembelajaran dengan menggunakan model pembelajaran Problem Based Learning dengan urut dan sistematis, (2) indikator hasil, Indikator hasil keaktifan diukur dengan menggunakan lembar observasi yang telah diolah sehingga dapat diketahui adanya peningkatan atau tidak. Adanya peningkatan keaktifan siswa dalam kegiatan pembelajaran dikatakan berhasil apabila rata-rata keaktifan siswa berada pada kategori aktif dalam pembelajaran. Sedangkan hasil belajar siswa diukur menggunakan soal evaluasi siklus I dan II. Hasil dari setiap siklus digunakan untuk mengetahui adanya peningkatan hasil belajar siswa. Indikator yang digunakan adalah Kriteria Ketuntasan Minimal (KKM). Hasil belajar pembelajaran tematik pada muatan pelajaran IPA meningkat apabila diatas $80 \%$ siswa memperoleh nilai diatas KKM. Standar KKM yang digunakan adalah 70 .

\section{B. HASIL PENELITIAN DAN PEMBAHASAN}

\section{Hasil Penelitian}

Penelitian ini dilaksanakan dalam 2 siklus. Siklus I dilaksanakan pada tanggal 13-15 Februari 2019. Siklus II dilaksanakan pada tanggal 18-20 Februari 2019. Setiap siklus dibagi menjadi 3 kali pertemuan, jadi total keseluruhan pertemuan dalam penelitian ini adalah 6 kali. Berikut ini dapat dilihat peningkatan keaktifan dan hasil belajar IPA siswa mulai dari kondisi awal (pra siklus), siklus I dan siklus II siswa kelas 4 SD Negeri Noborejo 01 tahun ajaran 2018/2019 dengan menggunakan model pembelajaran Problem Based Learning:

Tabel 1

Peningkatan Keaktifan Siswa Pra Siklus, Siklus I, dan Siklus II

\begin{tabular}{|c|c|c|c|}
\hline & Pra siklus & Siklus I & Siklus II \\
\hline Rata-rata & 77,47 & 95,44 & 118,32 \\
\hline Kategori & Kurang Aktif & Cukup Aktif & Aktif \\
\hline Skor Tertinggi & 108 & 110 & 128 \\
\hline Skor Terendah & 63 & 80 & 103 \\
\hline
\end{tabular}

Berdasarkan tabel 4.1 mengenai peningkatan keaktifan siswa pada saat Pra siklus, siklus I, dan siklus II, rata-rata keaktifan mengalami peningkatan. Pada saat Pra siklus (sebelum dikenai tindakan) rata-rata keaktifan hanya 77,47 atau berada pada kategori kurang aktif, setelah dilaksanakan siklus I rata-rata keaktifan siswa mengalami peningkatan menjadi 95,44 atau berada pada kategori cukup aktif dan pada siklus II ratarata keaktifan siswa 118,32 atau berada pada kategori aktif.

Berikut mengenai peningkatan keaktifan pada saat Pra siklus (kondisi awal), siklus I, dan siklus II, maka dapat dilihat pada gambar diagram batang 1: 


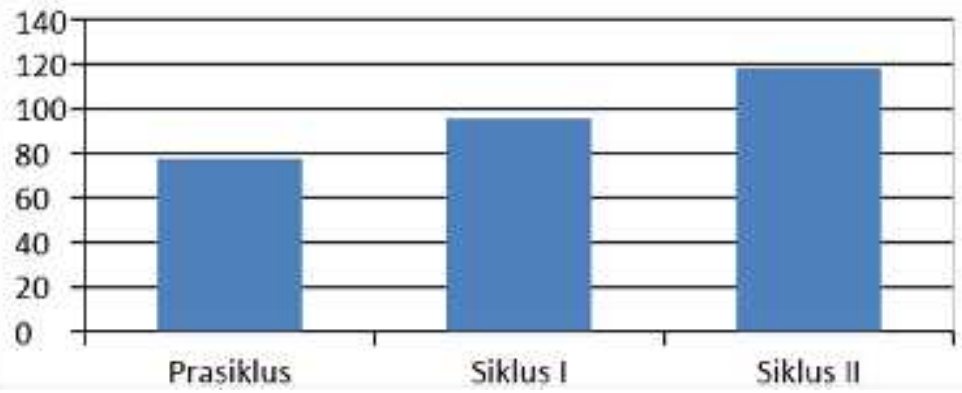

Gambar 1

\section{Peningkatan Rata-rata Keaktifan Siswa Pra siklus, Siklus I, Siklus II}

Berdasarkan grafik 1 terjadi peningkatan keaktifan siswa. Pada saat Pra siklus rata-rata keaktifan siswa sebanyak 77,47 dengan kategori kurang aktif, kemudian pada siklus I mengalami peningkatan menjadi 95,44 dengan kategori cukup Penerapan model pembelajaran Problem Based Learning berpengaruh juga terhadap hasil belajar IPA pada pembelajaran tematik siswa kelas 4 SD Negeri Noborejo 01 tahun ajaran 2018/2019. Agar aktif dan pada siklus II kembali mengalami peningkatan yaitu rata-rata keaktifan siswa menjadi 118,32 dengan kategori aktif. Jadi dapat disimpulkan bahwa setiap siklus rata-rata keaktifan siswa mengalami peningkatan.

dapat mengetahui peningkatan hasil belajar siswa dalam penelitian ini, peneliti menuliskan hasil belajar dalam bentuk tabel perbandingan sebagai berikut

\section{Tabel 2}

\section{Perbandingan Hasil Belajar IPA Pra siklus, Siklus I, dan Siklus II}

\begin{tabular}{|c|l|c|c|c|}
\hline Perubahan & \multicolumn{1}{|c|}{ Indikator } & $\begin{array}{c}\text { Pra } \\
\text { siklus }\end{array}$ & Siklus I & Siklus II \\
\hline $\begin{array}{c}\text { Hasil } \\
\text { Belajar }\end{array}$ & Nilai Rata-rata Siswa & 62,17 & 78,39 & 83,29 \\
\cline { 2 - 5 } & $\begin{array}{l}\text { Persentase Jumlah Siswa } \\
\text { Mencapai KKM }\end{array}$ & $38,23 \%$ & $67,64 \%$ & $82,36 \%$ \\
\hline
\end{tabular}

Berdasarkan tabel 2 hasil belajar siswa yang diperoleh dari setiap evaluasi didapatkan rata-rata yang mengalami peningkatan. Peningkatan dapat dilihat dari kondisi awal dengan rata-rata 62,17 dan terjadi peningkatan sebanyak 16,22 dengan rata-rata 78,39 pada siklus I. Rata-rata juga meningkat dari siklus I yaitu dari 78,39 menjadi 83,29 di siklus II atau meningkat sebanyak 4,9.

Selain rata-rata kelas, persentase perolehan KKM pun juga ikut meningkat. Persentase ketuntasan pada kondisi awal yaitu 38,23\% meningkat menjadi $67,64 \%$ pada siklus I atau meningkat sebanyak $29,41 \%$. Persentase ketuntasan pada siklus II yaitu $82,36 \%$ yang artinya mengalami peningkatan dari siklus I sebanyak $14,72 \%$.

Berdasarkan uraian diatas, grafik 2 adalah diagram batang hasil penelitian rata-rata hasil belajar siswa dari kondisi awal (Pra siklus), siklus I, dan siklus II untuk mengetahui peningkatan yang terjadi. 


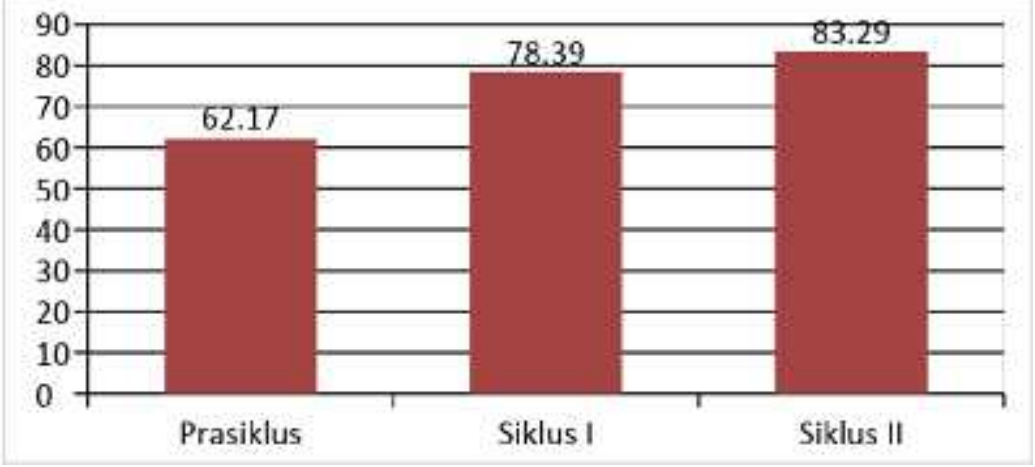

Gambar 2

Rata-rata Hasil Belajar

Sedangkan diagram batang yang berisikan persentase ketuntasan hasil belajar siswa dari kondisi awal (Pra siklus), siklus I, dan siklus II disajikan dalam grafik 3 berikut ini:

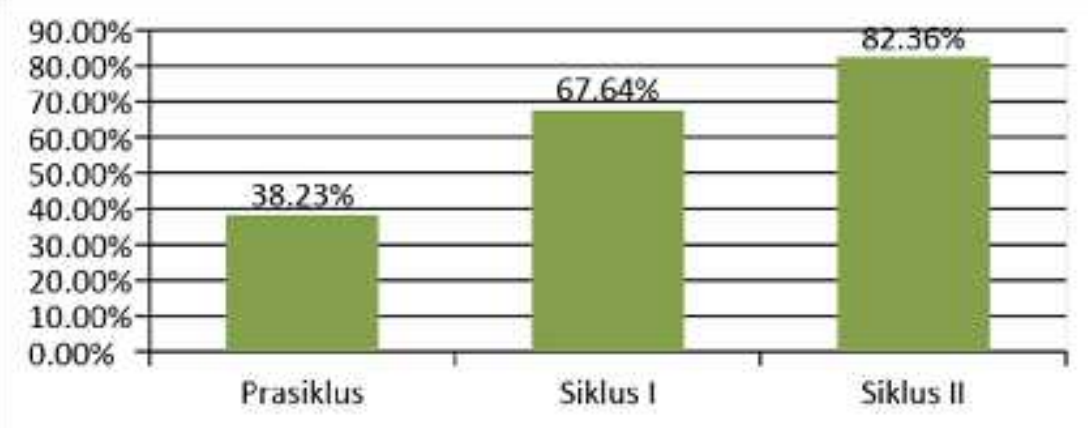

Gambar 3

Persentase Rata-rata Hasil Belajar Pra siklus, Siklus I, dan Siklus II

\section{Pembahasan}

Hasil penelitian yang dilakukan oleh peneliti pada siswa kelas 4 SD Negeri Noborejo 01 Salatiga dengan menggunakan model pembelajaran Problem Based Learning terlihat terjadi peningkatan pada keaktifan dan hasil belajar IPA siswa pada pembelajaran tematik mulai dari kondisi awal (pra siklus), siklus I sampai siklus II.

Peningkatan keaktifan dilihat dari data hasil observasi yang dilakukan oleh 4 observer pada kondisi awal atau Pra siklus, siklus I dan siklus II. Berdasarkan data yang telah dipaparkan oleh peneliti mulai dari Pra siklus, siklus I, dan siklus II dapat diambil kesimpulan bahwa dengan menggunakan model pembelajaran Problem Based Learning dapat meningkatkan keaktifan siswa pada pembelajaran tematik. Pada saat Pra siklus sebelum diterapkannya model pembelajaran Problem Based
Learning rata-rata keaktifan siswa sebesar 77,47 dengan kategori kurang aktif, skor tertinggi sebesar 108 dan skor terendah 63. Setelah dilaksanakan tindakan dengan menggunakan model pembelajaran Problem Based Learning pada siklus I, rata-rata keaktifan siswa sebesar 95,44 dengan kategori cukup aktif, skor tertinggi sebesar 110 dan skor terendah 80. Pada siklus I telah terjadi peningkatan keaktifan siswa, akan tetapi belum mencapai indikator kinerja yang peneliti tentukan yaitu ratarata keaktifan siswa berada pada kategori aktif.

Siklus II, rata-rata keaktifan siswa meningkat menjadi 118,32 dengan kategori aktif, skor tertinggi sebesar 123 dan terendah 103 dengan jumlah siswa dengan kriteria aktif sekali sebanyak 5 siswa $(14,71 \%)$ dan kategori aktif sebanyak 23 siswa $(67,65 \%)$, itu berarti siswa yang memiliki kategori aktif sekali dan aktif adalah sebanyak 28 siswa 
(82,35\%). Hal ini berarti indikator kinerja yang ditetapkan oleh peneliti sudah sesuai dengan hasil observasi keaktifan siswa pada siklus II yaitu ratarata keaktifan siswa berada pada kategori aktif.

Selain keaktifan yang meningkat, hasil belajar IPA siswa pada pembelajaran tematik juga mengalami peningkatan mulai dari kondisi awal dengan rata-rata kelas 62,17 meningkat menjadi 78,39 pada siklus I, kemudian meningkat menjadi 83,29 pada siklus II. Selain rata-rata kelas, peningkatan juga terlihat dari persentase ketuntasan, pada kondisi awal persentase ketuntasan hanya sebesar $38,23 \%$ meningkat menjadi $67,64 \%$ pada siklus I kemudian mengalami peningkatan sebesar 14,72\% pada siklus II menjadi 82,36\%. Dari hasil belajar tersebut terlihat bahwa ranah kognitif siswa mengalami peningkatan, akan tetapi pada ranah afektif dan psikomotorik siswa pun ikut mengalami peningkatan menjadi lebih baik lagi karena pengalaman-pengalaman belajar yang tidak hanya berfokus pada ranah kognitif saja.

Hasil penelitian tersebut sejalan dengan teori hasil belajar yang dikemukakan oleh Rusman (2017: 129) hasil belajar adalah sejumlah pengalaman yang diperoleh siswa yang mencakup ranah kognitif, afektif, dan psikomotorik. Bukan hanya ranah pengetahuan saja yang meningkat, akan tetapi secara keseluruhan baik sikap dan perilaku dapat meningkat melalui proses belajar. Hasil penelitian ini juga sesuai dengan pengertian hasil belajar yang diungkapkan oleh Kristin (2016: 78) bahwa hasil belajar adalah hasil yang diperoleh akibat dari suatu aktivitas yang dilakukan dan mengakibatkan terjadinya perubahan tingkah laku. Dalam penelitian ini, perubahan dan peningkatan yang terjadi tidak hanya sebatas pada aspek pengetahuan saja, namun juga pada aspek tingkah laku dan keterampilan siswa dapat meningkat menjadi lebih baik.

Berdasarkan uraian diatas maka, penerapan model pembelajaran Problem Based Learning pada siswa kelas 4 SD Negeri Noborejo 01 dapat meningkatkan keaktifan dan hasil belajar IPA pada pembelajaran tematik. Hasil penelitian ini memperkuat penelitian terdahulu seperti yang dilakukan oleh Sugi Oktari (2018) dengan judul penelitian "Peningkatan Hasil Belajar IPA dengan Model Problem Based Learning Berbantuan Media Audiovisual Kelas IV". Pada siklus I persentase keberhasilan siswa sebesar $71 \%$ dan pada siklus II meningkat menjadi $83 \%$.

Keunggulan penelitian ini dibandingkan penelitian sebelumnya yaitu penelitian ini mengukur keaktifan sekaligus hasil belajar IPA siswa pada pembelajaran tematik dengan menggunakan model pembelajaran Problem Based Learning. Selain itu dalam penelitian ini bukan hanya aspek kognitif yang dapat terlihat meningkat akan tetapi aspek afektif dan psikomotorik ikut meningkat. Dengan menggunakan model pembelajaran yang berbasis masalah maka siswa dituntut untuk lebih aktif pada saat proses pemecahan masalah. Penggunaan model pembelajaran Problem Based Learning juga dapat memudahkan dan memberikan pengalaman langsung baik bagi siswa maupun guru, sehingga pembelajaran tersebut akan menjadi lebih bermakna sesuai dengan materi yang telah diajarkan pada siswa kelas 4 SD Negeri Noborejo 01 Tahun Pelajaran 2018/2019. 


\section{SIMPULAN}

Berdasarkan hasil penelitian yang telah dilaksanakan di SD Negeri Noborejo 01 menggunakan model pembelajaran Problem Based Learning, maka dapat disimpulkan bahwa:

1. penerapan model pembelajaran Problem Based Learning untuk peningkatan keaktifan dan hasil belajar IPA pada pembelajaran tematik siswa kelas 4 SD Negeri Noborejo 01 Salatiga telah dilakukan dengan langkahlangkah sebagai berikut : menyampaikan tujuan pembelajaran, menyampaikan materi pelajaran dengan bantuan video, membentuk kelompok, mengerjakan permasalahan yang diberikan oleh guru berdasarkan materi yang dipelajari dengan diskusi kelompok, mempresentasikan hasil diskusi kelompok, serta mengerjakan soal evaluasi.

2. Hasil penelitian menunjukkan bahwa penerapan model pembelajaran Problem Based Learning dapat meningkatkan keaktifan siswa pada pembelajaran tematik siswa kelas 4 SD Negeri Noborejo 01 Salatiga. Hal tersebut dibuktikan dengan data peningkatan rata-rata keaktifan siswa pada kondisi awal (Pra siklus) yaitu sebesar 77,47 dengan kategori kurang aktif pada siklus I dan meningkat menjadi 95,44 dengan kategori cukup aktif. Pada siklus II rata-rata keaktifan siswa kembali meningkat dari siklus I menjadi 118,32 dengan kategori aktif.

3. Hasil penelitian menunjukkan bahwa penerapan model pembelajaran Problem Based Learning dapat meningkatkan hasil belajar IPA pada pembelajaran tematik siswa kelas 4 SD Negeri Noborejo 01. Hal tersebut dibuktikan dengan data mulai dari kondisi awal (Pra siklus) rata-rata nilai kelas sebesar 62,17 dengan persentase ketuntasan $38,23 \%$, pada siklus I meningkat menjadi 78,39 dengan persentase ketuntasan $67,64 \%$ dan mengalami peningkatan pada siklus II menjadi 83,29 dengan persentase ketuntasan sebesar $82,36 \%$.

\section{DAFTAR PUSTAKA}

Acesta, A. (2014). Penerapan Pendekatan Keterampilan Proses Sains Untuk Meningkatkan Hasil Belajar Siswa Dalam Pembelajaran IPA. Jurnal Ilmiah Pendidikan Dasar, 1(2).

Anugraheni, I. (2017). Penggunaan Portofolio dalam Perkuliahan Penilaian Pembelajaran. Jurnal Pendidikan Dasar Perkhasa, 246-258.

Arifin, Z. (2013). Evaluasi Pembelajaran. Bandung: PT. Remaja Rosdakarya.

Gunantara, G., Suarjana, I. M., \& Riastini, P. N. (2014). Penerapan model pembelajaran problem based learning untuk meningkatkan kemampuan pemecahan masalah matematika siswa kelas V. MIMBAR PGSD Undiksha, 2(1).

Hajar, I. (2013). Panduan Lengkap Kurikulum Tematik untuk SD/MI. Yogyakarta: DIVA Press.

Hariyanto, W. d. (2012). Pembelajaran Aktif. Bandung: PT. Remaja Rosdakarya.

Hosnan, M. (2016). Pendekatan Saintifik dan Kontekstual dalam Pembelajaran Abad 21. Bogor: Ghalia Indonesia.

Huda, M. (2013). Model-Model Pengajaran dan Pembelajaran. Yogyakarta: Pustaka Pelajar Offset.

Kristin, F. (2016). Efektivitas Model Pembelajaran Kooperatif Tipe STAD Ditinjau dari Hasil Belajar IPS Siswa Kelas 4 SD. Scholaria : Jurnal Pendidikan dan Kebudayaan, 74-79.

Mawardi, M. (2014). Pemberlakuan Kurikulum SD/MI Tahun 2013 dan Implikasinya Terhadap Upaya Memperbaiki Proses Pembelajaran Melalui PTK. Scholaria: Jurnal Pendidikan Dan Kebudayaan, 4(3), 107-121. 
Mulyasa. (2015). Guru dalam Implementasi Kurikulum 2013. Bandung: PT Remaja Rosdakarya.

Nurhadi, d. (2009). Pembelajaran Kontekstual dan penerapannya dalam KBK. Malang: Universitas Negeri Malang.

Oktari, S., Koeswati, H. D., \& Giarti, S. (2018). Peningkatan Hasil Belajar IPA Dengan Model Problem Based Learning Berbantuan Media Audiovisual Kelas IV SD. Pendekar: Jurnal Pendidikan Berkarakter, 1(1), 316-323.

Pamungkas, A. D. (2018). Meningkatkan Keaktifan dan Hasil Belajar Siswa Melalui Model Pembelajaran Problem Based Learning (PBL) pada Siswa Kelas 4 SD. Naturalistic: Jurnal Kajian Penelitian Pendidikan dan Pembelajaran Vol.3, 287-293.

Rusman. (2012). Model-Model Pembelajaran Mengembangkan Profesionalisme Guru. Jakarta: PT. RajaGrafindo Persada.
Rusman. (2016). Model-Model Pembelajaran Mengembangkan Profesionalisme Guru. Jakarta: PT. RajaGrafindo Persada.

Slameto. (2010). Belajar dan Faktor-Faktor yang Mempengaruhinya. Jakarta: Rineka Cipta.

Sunarto, L. (2013). Peningkatan Keaktifan Belajar Siswa Melalui Strategi Group Investigation Pada Mapel PKn Materi PerundangUndangan Siswa Kelas V SD Negeri 01 Gumeng Kecamatan Jenawi Kabupaten Karanganyar Tahun Pelajaran 2012/2013 (Doctoral dissertation, Universitas Muhammadiyah Surakarta).

Sudjana, N. (2004). Penilaian Hasil Proses Belajar Mengajar. Bandung: PT. Remaja Rosdakarya.

Sundayana, W. (2014). Pembelajaran Berbasis Tema. Jakarta: Erlangga. 